\title{
Szennyvíziszap kihelyezés rövidtávú következményeinek értékelési lehetősége Sentinel-2 alapú szántóföldi vegetációmonitoring alapján
}

\author{
*KovÁcs Ferenc, LADÁNYI Zsuzsanna \\ Szegedi Tudományegyetem, Geoinformatikai, Természet- és Környezetföldrajzi \\ Tanszék, Szeged
}

(Beérkezett: 2020.08.10;; Elfogadva: 2021.04.30.)

\section{Bevezetés}

A szennyvíziszap, szervesanyag-tartalma révén a talaj tápanyagutánpótlásra felhasználható a mezőgazdaságban (KELESSIDIS és STASINAKIS, 2012), amennyiben tulajdonságai megfelelnek a közegészségügyi és környezetvédelmi követelményeknek. Globálisan a városi szennyvíznek csak kis százalékát kezelik és hasznosítják, ugyanakkor a szennyvizek és szennyvíziszapok kezelése során a kórokozók, a nehézfémek és a káros szerves anyagok mennyiségének csökkentése szükséges a jogszabályokban elöírt mértékig; az így kezelt szennyvíziszap a 'biosolid' (SAGASTA et al., 2015). A szennyvíziszap talajban történő elhelyezése a talajok öntisztuló képessége miatt lehetséges, de a különböző talajtípusok csak bizonyos terhelési szintig képesek azok szürésére, biológiai és kémiai átalakítására (TAMÁS és BLASKÓ, 2008). Fontos, hogy a szennyvíziszap pihentetés után, vagy csak kezelt formában helyezhető ki a talajokra. A kezelt, száraz szennyvíziszapban a makrotápelem-tartalom hasonló az állati trágya használatánál tapasztaltakhoz. A trágyában lévő növények számára hasznosítható legfontosabb tápanyagok, azaz a nitrogén és a foszfor (TAMÁs et al., 2008; TOMÓCSIK et al., 2016), és a szervesanyagtartalom elérheti az 50\%-ot (VERMES, 2005). A körültekintő, hosszan tartó szennyvíziszap kihelyezés hozzájárulhat a humuszmennyiség és minőség növeléséhez. Az a növénytápláló hatás mellett javítja a talaj vízmegtartó képességét és tömörségét. A toxikus anyagoktól mentes iszap hatására a növények fejlődése erőteljesebb, kiegyensúlyozottabb, így a terméshozam a termés minőségi javulásával növekszik (SIMON és SZENTE, 2000; PETRÓCZKI, 2005). A szerves anyag minőségében és mennyiségében 1-2 év alatt bekövetkező kis változásokat nehéz elemezni, így a talajjavításra gyakorolt hatás értékelésére több év vagy évtized után van lehetőség (BANERJEE et al., 1997).

A szennyvízelvezetési és -tisztítási programok miatt növekvő szennyvíziszap felhasználást az európai uniós irányelvek is ösztönzik (91/271/EGK, 86/278/EGK) és hazánkban a 50/2001. (IV.3.) kormányrendelettel és a 36/2006. (V.18.) FVM rendelettel szabályozzák. Magyarországon az ilyen típusú szennyvíziszap kb. 40\%-át hasznosítják a mezőgazdaságban, ami megfelel az EU átlagnak (SZENNYVÍZISZAP KEZELÉSI ÉS HASZNOSÍTÁSI STRATÉGIA 2014-2023).

A szántóföldi kihelyezéssel a hulladékként kezelt iszap elhelyezés problémája is kezelhetö, illetve egy későbbi stádiumban haszon is realizálható. Kérdés, hogy a

*Levelezö szerzö: KovÁcs FERENC, Szegedi Tudományegyetem, Geoinformatikai, Természetés Környezetföldrajzi Tanszék, Szeged 6722, Egyetem utca 2-6.

E-mail: kovacsf@geo.u-szeged.hu 
kihelyezésnek rövidtávon, 1-2 éven belül lehet-e látható térbeli-statisztikai értelemben vett pozitív hatása a mezőgazdasági termelésre? Egy kezelt parcellán, a többi területtel összehasonlítva a növények elviekben dinamikusabban fejlődnek, dúsabb és egyenletesebb biomassza-produkcióval bírnak. A kérdés természetesen összetettebb és nem feledkezhetünk meg a területhasználati változásokról, vagy a növények fejlődését befolyásoló talajtani/klimatológiai paraméterekröl. A szennyvíziszap kihelyezés hatásainak földrajzi megfigyelésével elsődleges célunk a vegetáció, - a szántóföldi növénytermesztés - lehető legnagyobb idő- és térbeli felbontású, 2016-2019 közötti 4 évre vonatkozó monitoring vizsgálata volt.

\section{A mintaterületek jellemzése}

A távérzékelési módszereken alapuló adatgyüjtést és a statisztikai, térbeli vizsgálatot a mintaterületen folyó, FARSANG et al. (2020) szerinti talajtani mintavételezéssel párhuzamosan, különbözö növényeket termelő, három mezögazdasági parcellán elhelyezkedő, összesen 14 db, 50 m x 50 m-es, homogén felszínfedettségü egységekre, kvadrátokra vonatkozóan végeztük. A kvadrátok egy része szennyvíziszappal kezelt területeket mintáz, míg a mellettük lévő, nagyon hasonló tulajdonságokkal bíró, kihelyezéssel nem rendelkező kvadrátok kontroll területként szolgáltak a vizsgálathoz. A mintaterületek a Körös-Maros közén találhatók Újkígyós és Szabadkígyós, illetve Kardos és Kondoros települések közelében (1. ábra). A kvadrátokat párosával helyeztük el; Újkígyós esetében: 1t-2t, 3t-4t, 6t-7t, 9t-10t (a parcella közepének EOV koordinátái: X: 803030, Y: 140770), Kardos esetében: 10t-11t, 12t-13t (X: 778200, Y: 161990) és 14t-15t (X: 779700, Y: 160320) elnevezésekkel.

A Maros hordalékkúpon, Békési-háton fekvő újkígyósi kvadrátok 90-92 m tszf. magasságban, alföldi mészlepedékes csernozjom talajon, míg a keletebbre, a hordalékkúp peremén, a Békési-síkon lévő kardosi kvadrátok 84-85 m tszf. magasságban, csernozjom és réti csernozjom talajokon találhatók. A DOSoReMI (2017), AGROTOPO (1994) digitális talajtérképek alapján a felső 0-30 cm-es réteg agyag-iszap-homok szemcseméret frakció az újkígyósi parcellákon körülbelül $10 \%-10 \%-25 \%$; ́́gy vízgazdálkodása gyengén víztartó. A felső talajréteg vályog (homokos vályog) textúra osztályának 2-3\%-os szervesanyag-tartalma van. Kardos parcelláin azonban jó víztartó talajok vannak. Ezek az előző mintaterülethez képest nagyobb agyag és iszap szemcseméretűek, de kisebb a homok szemcsefrakciójuk $(30 \%-35 \%-5 \%)$. Az iszapos agyagos vályog textúrán kívül a szervesanyag-tartalom is nagyobb, 3-4\%. A természetes termékenységet kifejező talajértékszám 70-80\% az újkígyósi $50-60 \%$-hoz képest. Az újkígyósi mintaterület talajparamétereiben a kihelyezések mellett az utóbbi 5 évben nem történt lényeges változás, csupán a N- és a P-tartalom lett nagyobb (LADÁNYI et al., 2020). 


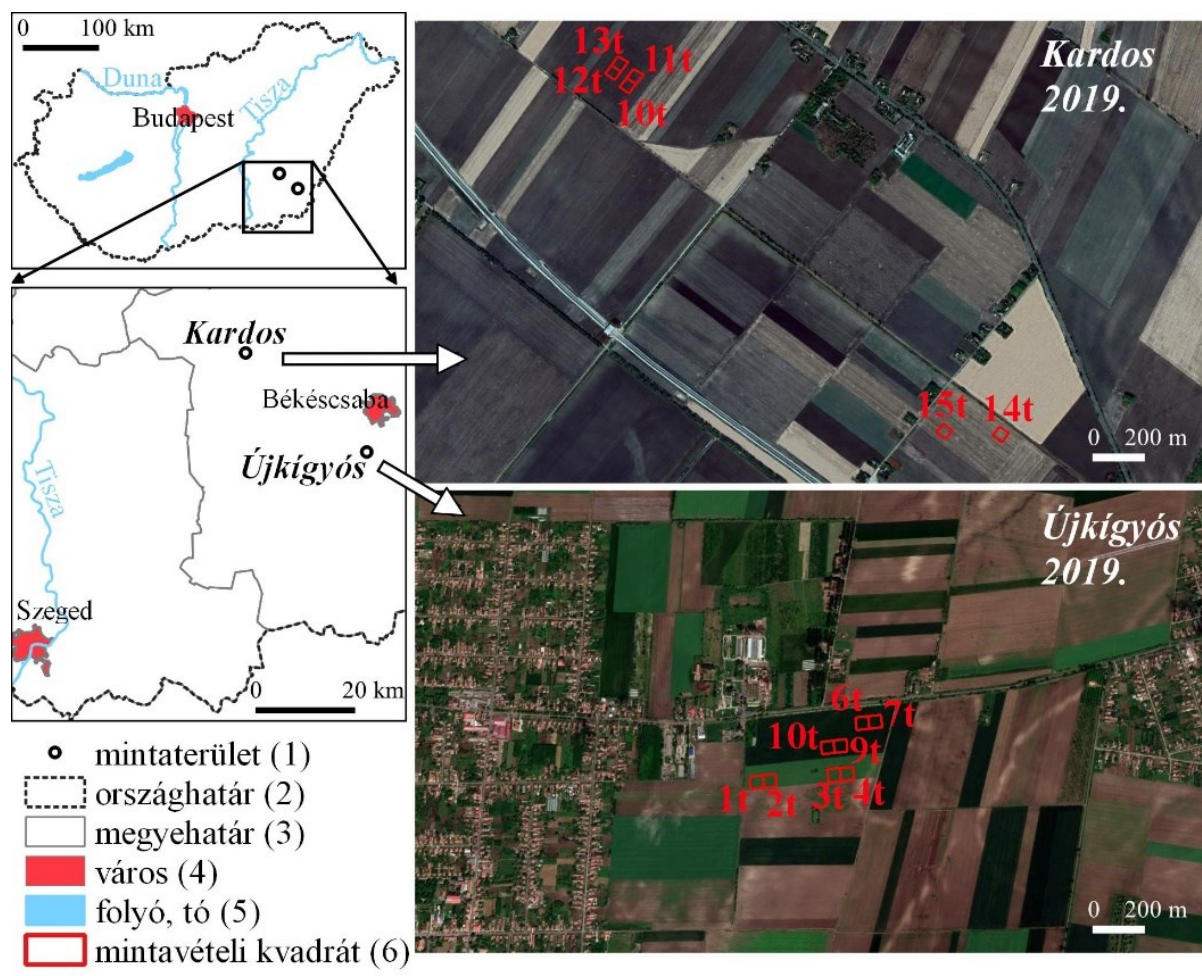

\section{1. ábra}

Kardos és Kondoros, illetve Újkígyós és Szabadkígyós között elhelyezkedő kvadrátok

(10t-15t, illetve $1 \mathrm{t}-4 \mathrm{t}, 6 \mathrm{t}-7 \mathrm{t}, 9 \mathrm{t}-10 \mathrm{t})$

A mintaterületre jellemző mezőgazdasági termelést a klímaváltozás alapvetően befolyásolja; 1983-2012 között az évi középhőmérséklet 1,2-1,3 ${ }^{\circ} \mathrm{C}$-al, a nyári napok száma 20-25 nappal, míg a hőhullámos napok száma 14 nappal nőtt (LAKATOS et al., 2014). A csapadék változásában dominál a szélsőséges jelleg; 2-6 nappal hosszabbak és egyre tartósabbak a tavaszi száraz időszakok. MezősI et al. (2016) szerint a következő 2-3 évtizedben, a 2050-ig fokozódó aszályhelyzetben a talajmüvelés szerepe előtérbe kerül. Mintaterületünkön a vizsgált időszakban, a nyári félév középhőmérséklete az 1970-2000 közötti normálértékhez képest $+1,2-2{ }^{\circ} \mathrm{C}$-al magasabb, míg a csapadékösszeg 2016-2018 között -41- -71 mm-el kevesebb és csak 2019-ben hullott - a májusi esőknek köszönhetően - 84 mm-el több csapadék (2. ábra). Az Operatív Vízhiány Értékelő és Előrejelző Rendszerben bevezetett meteorológiai aszályindex (FIALA et al., 2018) szerint Kardos mintaterület 1,15-os értéke nagyobb, mint az Újkígyóson mért 1,11, vagyis a kardosi terület enyhén szárazabb. 2016-2019 között egy-két hónapot leszámítva a mintaterületek aszálymentesek; az újkígyósi mintaterületen a 2017. év a legkevésbé csapadékos és a legmelegebb, legszárazabb, míg Kardoson a 2018. év volt hasonló. A 2. ábrához képest különbség Kardoson, hogy a 2017. júniusi csapadék kétszer több, viszont a 2019. évi májusi érték fele annyi volt. A vízellátást meghatározó talajvízszint 
klimatikus hatásokra való érzékenységénél jellemzö, hogy a hordalékkúp központi része - Újkígyós - felé az érzékenység nő, míg a peremi részek - Kardos - felé csökken (RAKONCZAI és FEHÉR, 2015).

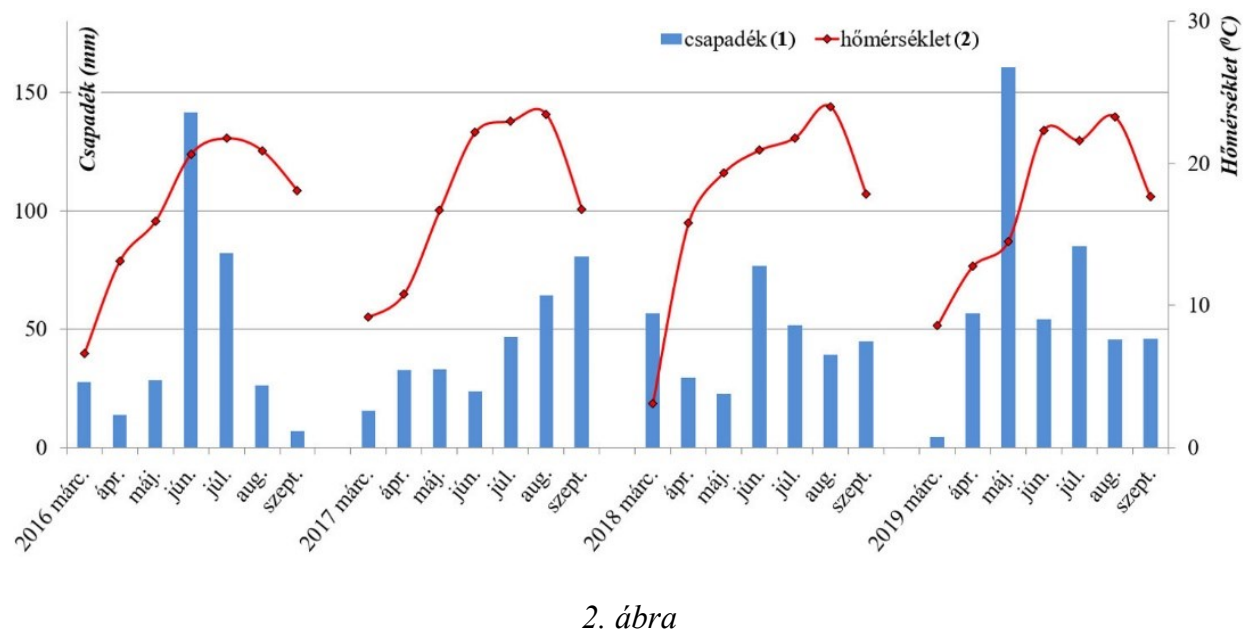

Békéscsaba állomás havi csapadékösszeg és középhőmérséklet értékei 2016-2019 között (adatok: ogimet.com, aszalymonitoring.vizugy.hu)

\section{1. táblázat}

A kardosi és újkígyósi mintaterületi kvadrátokon termelt növények 2016 és 2019 között

\begin{tabular}{|c|c|c|c|c|}
\hline Újkígyós / év & 2016 & 2017 & 2018 & 2019 \\
\hline $1 \mathrm{t}$ & kukorica (1) & olajretek (4) & őszi búza (5) & repce \\
\hline $2 \mathrm{t}$ & kukorica & olajretek & őszi búza & repce \\
\hline $3 \mathrm{t}$ & kukorica & olajretek & őszi búza & repce \\
\hline $4 \mathrm{t}$ & kukorica & olajretek & őszi búza & repce \\
\hline $6 t$ & repce (2) & kukorica & kukorica & öszi búza \\
\hline $7 \mathrm{t}$ & repce & kukorica & kukorica & öszi búza \\
\hline $9 \mathrm{t}$ & napraforgó (3) & kukorica & kukorica & öszi búza \\
\hline $10 \mathrm{t}$ & napraforgó & kukorica & kukorica & őszi búza \\
\hline Kardos / év & 2016 & 2017 & 2018 & 2019 \\
\hline $10 \mathrm{t}$ & napraforgó & őszi búza & napraforgó & őszi búza \\
\hline $11 \mathrm{t}$ & napraforgó & őszi búza & napraforgó & őszi búza \\
\hline $12 \mathrm{t}$ & napraforgó & őszi búza & napraforgó & őszi búza \\
\hline $13 \mathrm{t}$ & napraforgó & őszi búza & napraforgó & őszi búza \\
\hline $14 \mathrm{t}$ & napraforgó & őszi búza & kukorica & kukorica \\
\hline $15 \mathrm{t}$ & napraforgó & kukorica & kukorica & kukorica \\
\hline
\end{tabular}

Az évtizedek óta müvelt területen jellemzően őszi búzát, kukoricát, napraforgót, repcét, olajretket termesztenek (1. táblázat). 2016-2019 között Újkígyóson az ugyanazon parcellán fekvő 1t-4t mintakvadrátok felszínfedettsége változó: 2016-ban kukorica, 2017-ben olajretek, 2018-ban őszi búza, 2019-ben repce. A különbözö 
parcellákon fekvő 6t-7t és 9t-10t kvadrátokon 2016-ban még különböző növényeket termesztettek (repcét, illetve napraforgót), majd 2017-18-ban egyöntetűen kukoricát, 2019-ben őszi búzát (1. ábra).

A növényzetet a Google Earth adatbázis nagy $(<=2 \mathrm{~m} /$ pixel) felbontású müholdképeivel és a Sentinel-2 müholdfelvételek összehasonlító értelmezésével pontosítottuk (pl. Kardos mintaterület 2017. és 2018. évek területhasználata esetén).

Az 1t-4t-n azt a részben kezelt területet mintáztuk, ahová 2017 októberében szennyvíziszapot helyeztünk ki. Részben kontroll területen vannak a $6 \mathrm{t}-7 \mathrm{t}$ kvadrátok, mert itt csak 2018 ősszel helyeztünk ki szennyvíziszapot, míg a 9t-10t kvadrátok egyértelmüen kezeletlen, kontroll területek.

Kardos esetében a rendelkezésre álló müholdfelvételek és adatok alapján a 10t-11t és 12t-13t kvadrátok az 1. ábra szerint egy parcellán belül láthatók, ugyanazzal a váltógazdálkodással; 2016 és 2018-ban napraforgót termeltek, 2017 és 2019ben öszi búzát. A $14 \mathrm{t}$ és $15 \mathrm{t}$ területhasználata 2016-ban még szintén napraforgó, de 2017-ben csak a 14t-n volt őszi búza míg a 15t-n kukorica. 2018-19-ben már egyöntetü a kukoricatermelés, így ebben a két évben különböztek a 10t-13t kvadrátoktól. Kardoson a 10t, 11t és 14t-t határoltuk le olyan parcellákon, ahol 2017 összel volt kihelyezés, míg 12t-, 13t- és 15t-t kontrollterületekként alkalmaztuk.

\section{Adat és módszer}

A müholdas távérzékelés agrártudományi alkalmazásai (aszálymonitoring, termésbecslés) mellett az új felhasználók már az üzleti/agrárgazdasági alapú, drón felhasználások számát gyarapítják (PURI et al., 2018, KovÁCS et al., 2019, SZABÓ et al., 2019). Parcella vizsgálatokhoz elsősorban a nagy- és nagyon nagy felbontású felvételezések (cellaméret $<=2 \mathrm{~m}$ ) szükségesek, amik költségesek, ha azokat a multispektrális monitoring nagy időfelbontásával tervezik.

2. táblázat

Alkalmazott Sentinel-2 és LANDSAT-8 felvételek paraméterei

(adatok: ESA, NASA)

\begin{tabular}{|c|c|c|c|}
\hline Mủhold / érzékelő & $\begin{array}{c}\text { Multispektrális } \\
\text { felvételek (1) }\end{array}$ & $\begin{array}{c}\text { Alkalmazott spektrális sávok } \\
\text { közepes hullámhossza (2) }\end{array}$ & $\begin{array}{c}\text { Térbeli } \\
\text { felbontás (3) }\end{array}$ \\
\hline & 20 felvétel / 2016 & B2: $492,4 / 492,1 \mathrm{~nm}$ & \\
Sentinel-2A / 2B & 14 felvétel / 2017 & B4: $664,6 / 665 \mathrm{~nm}$ & $10 \mathrm{~m}$ \\
& 34 felvétel / 2018 & B8: $832,8 / 833 \mathrm{~nm}$ & \\
& 29 felvétel / 2019 & & $30 \mathrm{~m}$ \\
\hline & 11 felvétel / 2016 & B2: $482,5 \mathrm{~nm}$ & \\
\hline
\end{tabular}

A rendszeres szennyvíziszap kihelyezések biomassza produkcióra gyakorolt hatását egy-egy parcellára, 2-3 éves időtartammal a távérzékelés módszereivel 
kezdtük meg (LADÁNYI et al., 2018). Az elsődlegesen alkalmazott Sentinel-2A és 2B multispektrális müholdképek $10 \mathrm{~m}$ geometriai- és 3-5 napos időfelbontásúak (2. táblázat). Az ingyenes, gyengébb felbontású LANDSAT 8 másodlagos szenzorként egészítette ki az elemzést. A VERMOTE et al. (2016) és LOUIS et al. (2019) szerinti, atmoszférikusan korrigált, Level-2 felhömentes felvételeket értékeltük; összesen $97 \mathrm{db}$ Sentinel-2 (S2) és 33 db Landsat-8 (L8) müholdképet. A március végi időpontokkal kiegészített vegetációs periódus föleg a 2018-2019 években jelentett sok S2 képet, de a felhőfedettség miatt a 2016. évben nincs júliusi felvételünk. Az újkígyósi kvadrátokra a 2019. év április-május, valamint a kardosi parcellákra a 2017. év június és 2018. év július is felvétel nélküli.

A felvételezés idejét az adott növény fejlődését meghatározó (aratást megelőző) 3 hónapra célszerủ tervezni, ami növény fajonként különböző (pl. őszi búza: IVVI, kukorica: VI-VIII). A parcellákon évenként más növényekkel is gazdálkodnak és a különbözö években változó a képi fedettség (tavaszi, kora nyári időszakban sok a felhö), így sok felvétellel is korlátozott az összehasonlítás.

Az általánosan alkalmazott Normalized Difference Vegetation Index (NDVI) és a továbbfejlesztett, a talaj és az atmoszféra hatását redukáló Enhanced Vegetation Index (EVI) segítségével mérni lehet a növények fotoszintetikus aktivitását, és a biomassza tömeg változásait (BANNARI et al., 1995), aminek a klorofilltartalom mellett fontos eleme a növényben jelen lévő víz (1. és 2. egyenletek).

$$
\begin{gathered}
\text { NDVI }=\frac{\text { NIR }- \text { Red }}{\text { NIR }+ \text { Red }} \\
\text { EVI }=\mathrm{G} * \frac{\mathrm{NIR}-\text { Red }}{\mathrm{NIR}+\mathrm{C}_{1} * \text { Red }+\mathrm{C}_{2} * \text { Blue }+\mathrm{L}}
\end{gathered}
$$

NIR $=$ közeli infravörös hullámhossz-tartomány, Red $=$ látható fény vörös hullámhossztartomány, Blue = látható fény kék hullámhossz-tartomány, $\mathrm{L}=1, \mathrm{C}_{1}=6, \mathrm{C}_{2}=7,5$, és $\mathrm{G}=2,5$.

HUETE et al. (2002) szerint az EVI érzékenyebb a vegetációval sürübben borított területeken. Jobban kivehetők a térbeli és a növényfajták közötti különbségek és a fiziológiai és a levél szerkezetben lévő eltérések. Az NDVI általános vegetációs képet ad a területről és hasznos a csekély vegetációs fedettség és időbeni dinamikája megfigyelésében, de az EVI-nél alapvetően magasabb értéke hamarabb telítődik, és hiába nő a fitomassza tömege, a reflektancia nem emelkedik. Értéke regionális léptékben jól mutatja az agrárgazdálkodásban a vetés utáni időszakban a biomasszanövekedéssel, illetve az aratás után a -csökkenéssel jellemezhetö periódusokat (SZABÓ et al., 2019).

Nagy felbontású, évtizedes multispektrális elemzés szerint a szennyvíziszap kezeléssel a pár éven belül megfigyelhető, rövid távú hatások változók, míg egy hosszabb, körülbelül 10 éves távon a növények növekedésében pozitív a változás (ÁLVAREZ et al., 2014). A megnövekedett elemtartalom (pl. foszfor) a talajban a multispektrális felvételeken meghatározható, illetve a nehézfémmel terhelt növények megkülönböztethetők; elsősorban a 600-800 nm-es hullámhossz-tartományban 
jellemzők az eltérések a nem kezelt területektől (SRIDHAR et al., 2009, 2011). A Sentinel-2 rendelkezik vörös él („,red edge”) sávokkal, amelyekkel a vegetáción a környezeti stressz hatékonyabban mérhető, és az erre kifejlesztett indexszel mérhető a növényekben felhalmozódó nehézfém-tartalom (ZHANG et al., 2018).

Az S2 és L8 szenzorok 2016-2018 között 15 időpontban felvételeztek azonos napon vagy kis, +/-2 napos különbséggel. Az EVI determinációs együttható $\left(\mathrm{R}^{2}>=0,8\right)$ alapján a két szenzor értékeit nem alkalmaztuk együtt, az L8 EVI/NDVI-t (Vegetation Index - VI) csak összehasonlításként, a Sentinel alapú eredményeink igazolására használtuk a statisztikai vizsgálatban.

\section{Eredmények és értékelés}

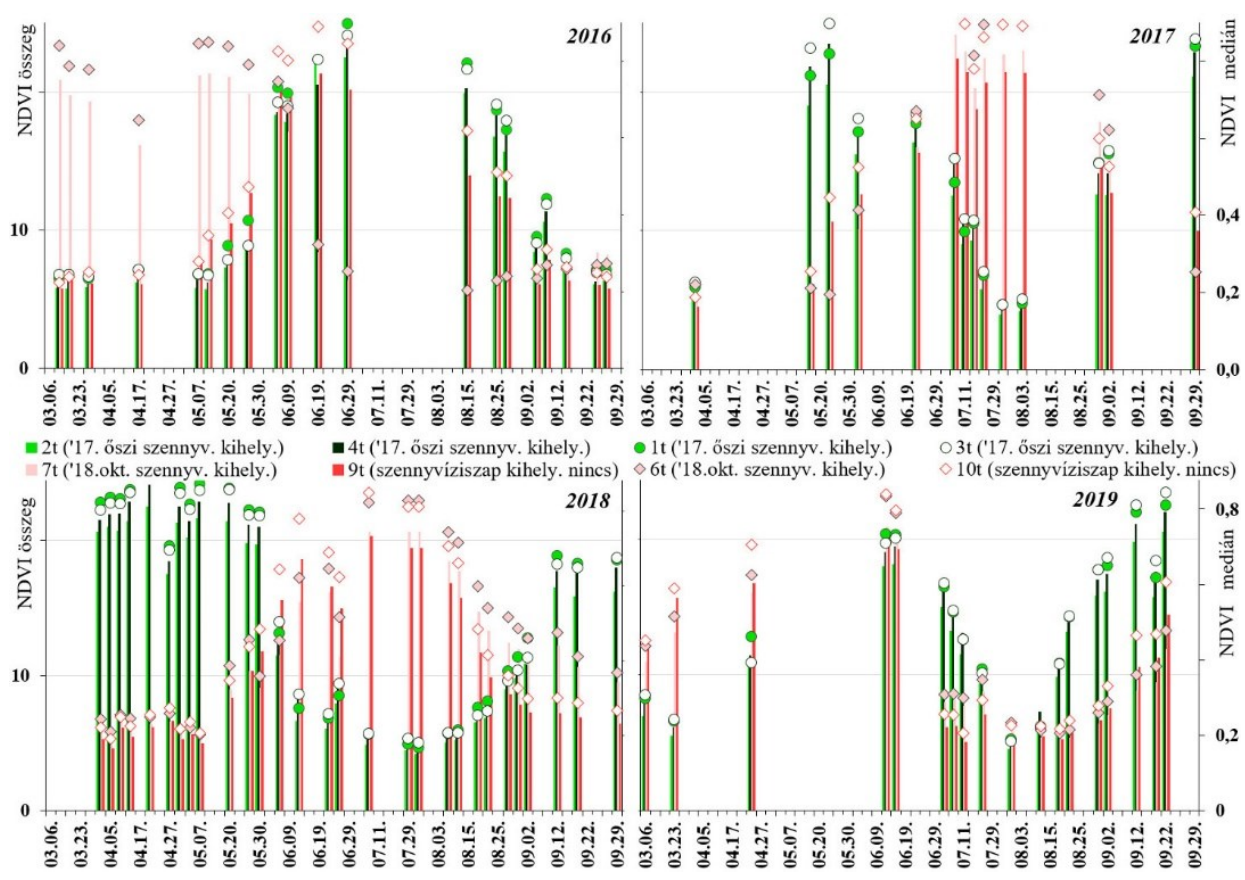

3. ábra

Újkígyós mintaterületi kvadrátok NDVI medián és összeg értékei 2016-2019 között (pontok: NDVI medián, oszlopok: NDVI összeg)

A termelt növények (őszi búza, kukorica, napraforgó, repce) vegetációs ciklus különbsége és a mintaterületeken megadott területhasználati változások jól láthatók az VI értékeken (3-6. ábrák), igaz az időbeli felbontás - az adott hónapokban elérhető képek száma az egyes években - némileg megnehezíti a különböző évek eredményeinek összevetését. A görbék futása a vegetációs fejlődésnek megfelelő; pl. az őszi búza tavaszi, eleve nagy VI értékei a júniusi aratással gyorsan csökkenők, míg a kukorica és a napraforgó május elején indul fejlődésnek és augusztus végén 
takarítják be. Az azonos területhasználatú kvadrát-párok értékei gyakorlatilag egyformák, különbség a kukoricánál figyelhető meg az 1t-2t és 3t-4t esetében 2016, valamint $6 \mathrm{t}-7 \mathrm{t}$, 9t-10t és $14 \mathrm{t}-15 \mathrm{t}$ esetében 2017-2018 május-júniusban. A statisztika szerint változatos térbeli különbséget mutat az olajretek 2017-ben az 1t-4t területeken. Az NDVI a csúcsértékekben nagyobb változékonyságot mutat, kisebb csökkenésekre-növekedésekre érzékeny, de a nagyon magas értékeknél telítődés jellemzi. A biomassza-produkció ingadozását, kisebb növekedését, csökkenését okozhatja gyomosodás, vagy pl. csapadékesemény miatti víz megjelenés; ilyen a $6 \mathrm{t}$ kvadrát aratás után 2016-ban, vagy az 1t és 3t kvadrátok 2018-ban. Legnagyobb átlagértékek a napraforgóban és a kukoricában láthatók. A teljes 2016-2019 közötti időtartamra megállapítva sem Újkígyós, sem Kardos mintaterületeken összegzett biomassza produktum nem mutat szignifikáns változást egyik index esetében sem.

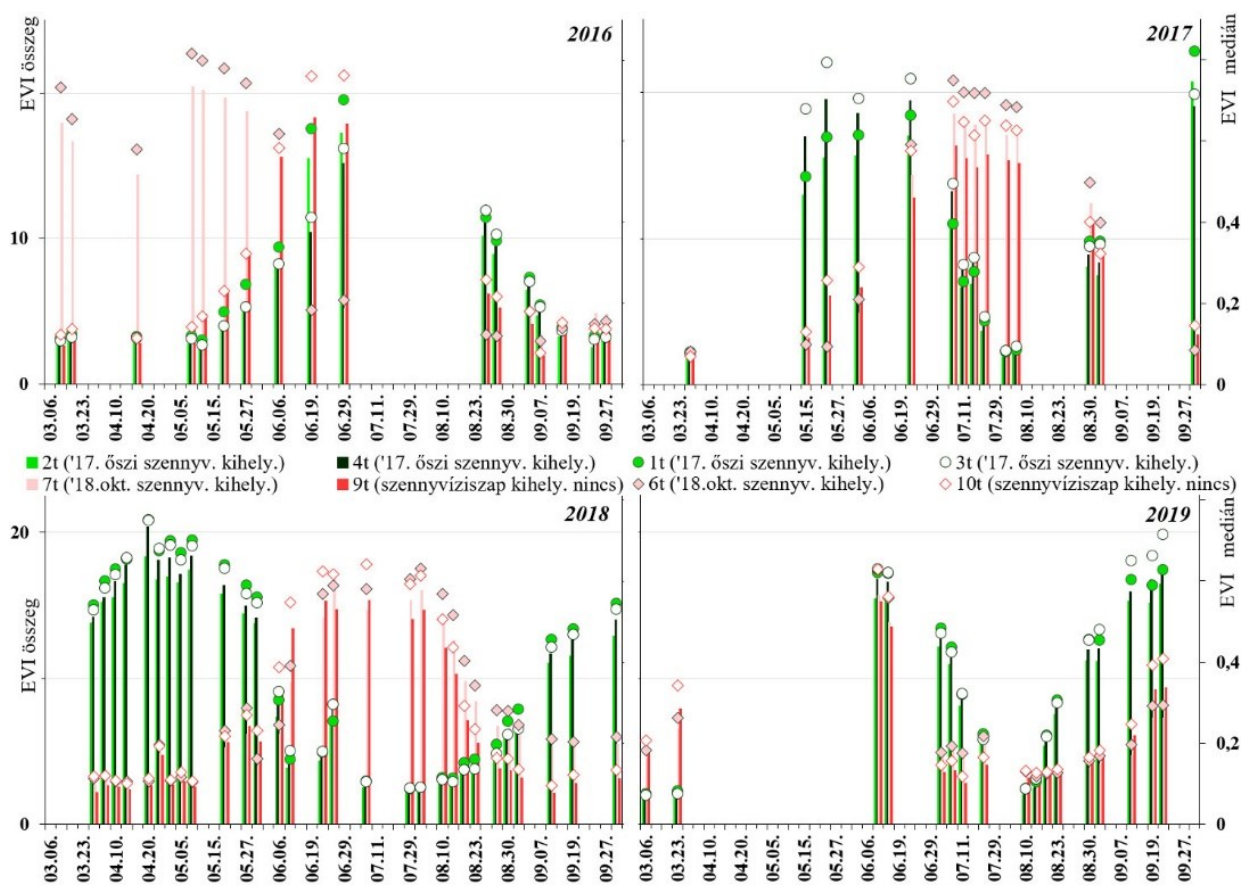

\section{4. ábra}

Újkígyós mintaterületi kvadrátok EVI medián és összeg értékei 2016-2019 között (pontok: EVI medián, oszlopok: EVI összeg)

Az NDVI értéke mindig nagyobb az EVI-nél (csak ritkán, dús vegetáció esetén fordul elő nagyobb EVI érték). A különbség jellemzöen $+0,08-0,2$ körüli, ami a biomassza produktum csúcsidőszakában akár $+0,35-0,4$ is lehet; az NDVI és EVI közötti különbség a mintaterületen az újkígyósi kvadrátokon nagyobb, illetve a szennyvíziszappal kezelt területeken jellemzően kisebb. A dús vegetációt érdemes az EVI alapján értelmezni, viszont a biomassza produkció növekedése jobban 
megkülönböztethető az NDVI alapján, illetve esetenként a vegetációtípusok különbsége is jobban értékelhető ezzel az indexszel. Az NDVI-ből több adat is áll rendelkezésre képi hibák miatt. A két indexet érdemes együtt használni az értékeléskor; látványosak a 6t-7t területek különböző EVI és NDVI értékei a 2016. és 2017. években.

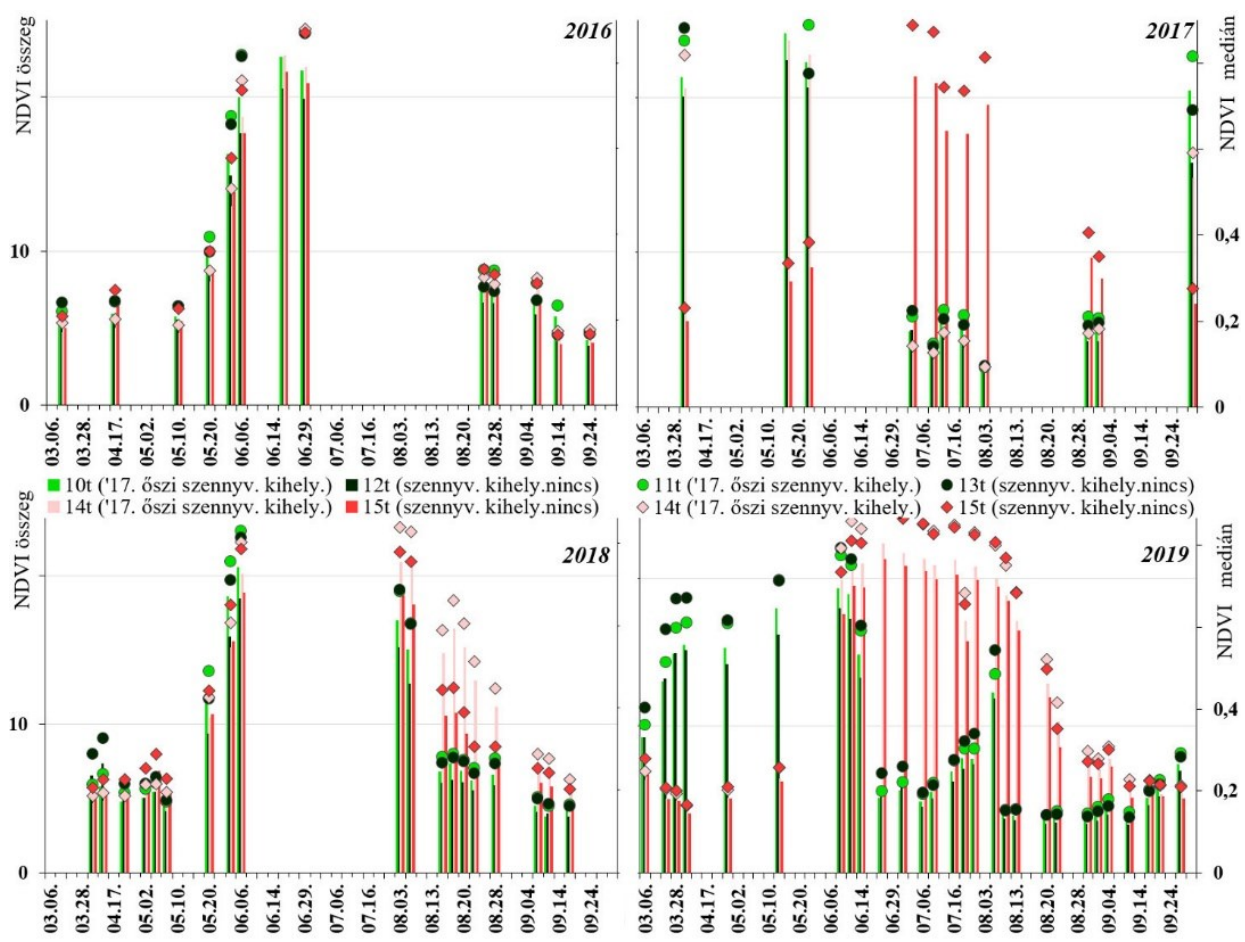

\section{5. ábra}

Kardos mintaterületi kvadrátok NDVI medián és összeg értékei 2016-2019 között (pontok: NDVI medián, oszlopok:NDVI összeg)

A kihelyezés hatását a repce termelésre Újkígyóson tudtuk megvizsgálni. Az 1t-4t területek, kihelyezés utáni (2019. évi) produktum kontroll értékeit a 2016. évi 6t-7t kvadrátokból vettük. A 2019. évi, körülbelül 1 hónappal későbbi kizöldülés és aratás miatt a VI értékek korlátozottan hasonlíthatók össze, de látható, hogy a 2016. évi csúcsértékek - föleg az EVI-nél - nagyobbak, és az adatok futásában sincs különbség, így a kihelyezésnek a repcét termelö kvadrátok esetében véleményünk szerint nincs hatása. Az augusztus-szeptemberi különbség a következő évi termésre utal és látható, hogy 2017-ben kukorica követte a repcét, míg 2020-ban őszi búza. 


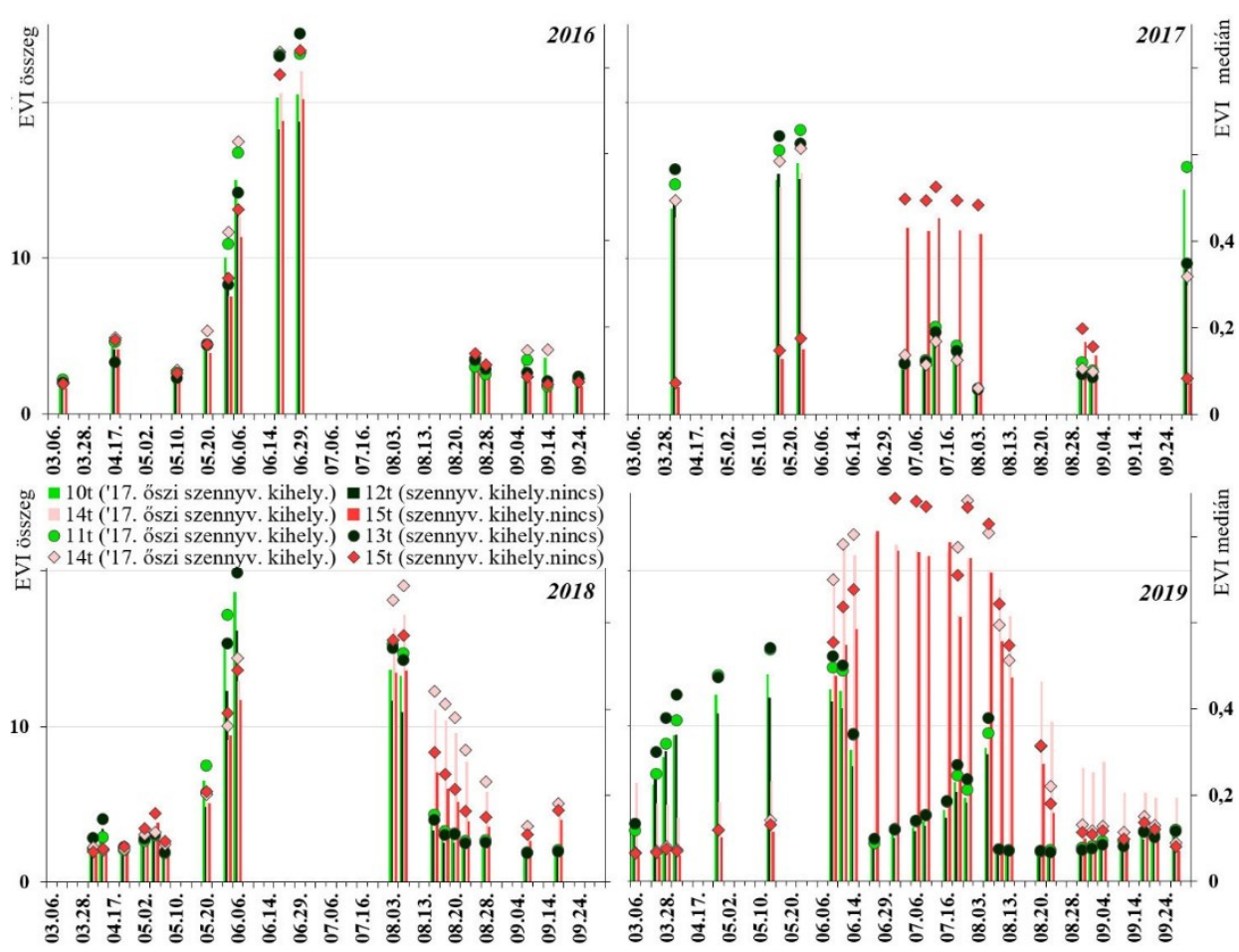

6. ábra

Kardos mintaterületi kvadrátok EVI medián és összeg értékei 2016-2019 között (pontok: EVI medián, oszlopok:EVI összeg)

A napraforgó biomassza-produkcióra gyakorolt hatás értékelésénél a kardosi 10t-11t kvadrátok 2018. évi VI értékeinek kontrollja a 2016. évben a teljes kardosi mintaterület (10t-15t), illetve Újkígyós 9t-10t kvadrátjai voltak. A minkakvadrátokon lévő növények növekedési üteme eltérő. A hasonló, kicsi áprilisi VI értékek 2016-hoz képest 2018. májusban nagyon intenzíven növekedtek - egy hét alatt közel 3-szoros VI értéket produkálva - és június elejére 0,2-0,3-el magasabb EVI értéket mutattak az iszap kihelyezésének területén (7. ábra). 2016-ban Újkígyóson a kardosi - 10t-15t - területnél is kevesebb volt a VI alapú terméshozam. Az NDVI 2018. májusi időszakban mutatta a legnagyobb, 0,1-0,23 különbségeket, ami június elejére tulajdonképpen megszünt. A napraforgónál tapasztalható jelentős különbségben - a klimatikus paraméterek ismeretében - szerepet játszhatott a 2017. évi iszapkihelyezés. 


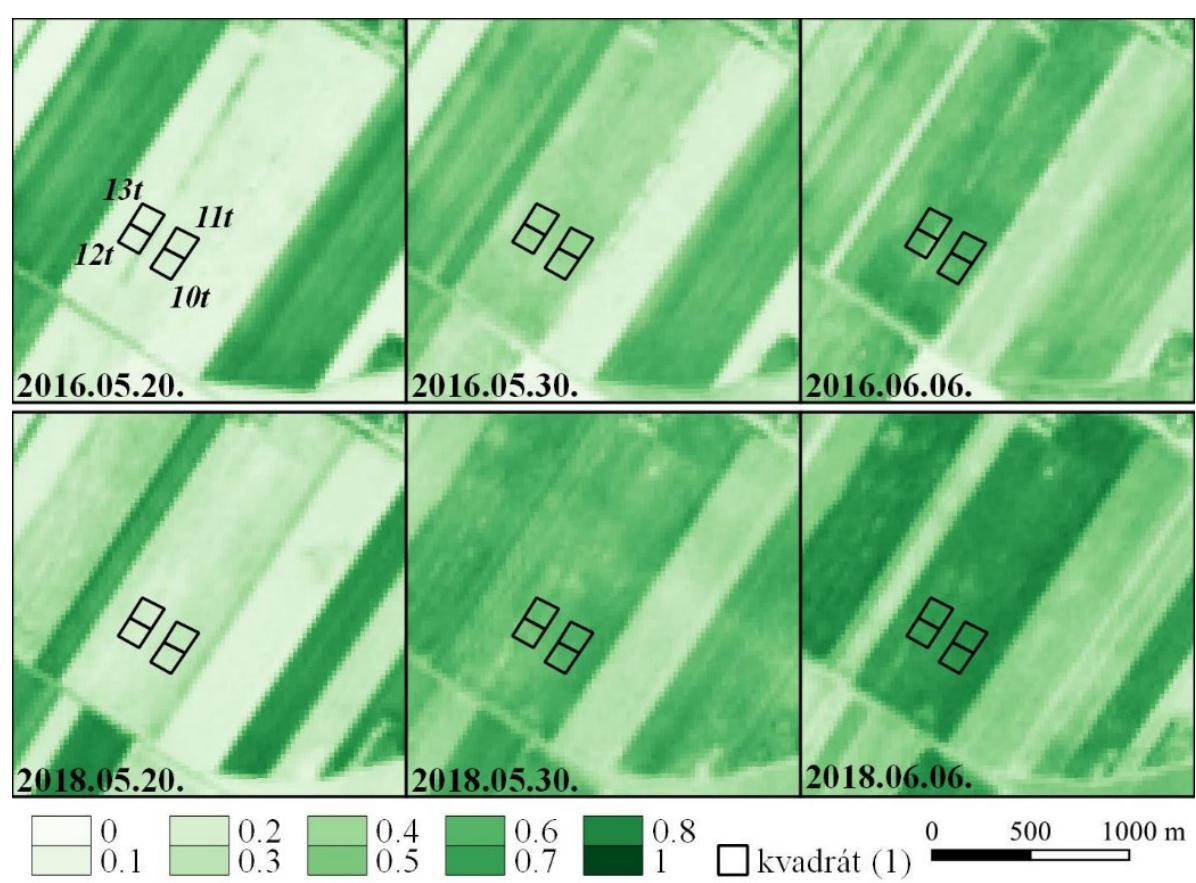

7. ábra

A 2017. évi szennyvíziszap kihelyezés rövidtávú hatása a napraforgó termesztésre a kardosi mintaparcellákon, Sentinel-2 EVI adatok alapján

A szennyvíziszap hatásának kukoricán megfigyelhetö következményét Kardos 14t kvadráton vizsgáltuk, ahol a 2017. évi kihelyezést követő 2018-2019. évi VI értékekhez kontrollként elsősorban a közeli Kardos 15t 2017-2019 közötti három év értékei szolgáltak (8. ábra). A 14t 2018. évi EVI adatai tavasszal még a 15t-vel megegyező értéket mutatnak, viszont az augusztusi aratást megelözően a kezelt területen már minimum 0,1-el nagyobb EVI értékek láthatók. A 14t-15t közötti különbség 2019. június-júliusában folyamatosan 0,05-0,12 közötti EVI értéket mutat és a két görbe csak augusztusra egyenlítődik ki. Ez a 2019. évi különbség az NDVI adatokban nincs jelen. A 14t 2019. évi kukorica EVI értékek a legkiemelkedőbbek a teljes vizsgálati időszak összes mintaterületét tekintve; június második felétől augusztus első feléig 0,8 fölöttiek, júliusban pedig 0,9 fölöttiek az átlagértékek. A 15t kontrollterület 2017. évi - aszályos - EVI értékei a 2019-es adatoknak csak 55-60\%át mutatják, így a 14t terület vizsgált értékeitől még jobban elmaradnak. Különösen szembeötlö az EVI alkalmazásának előnye a mintaterületen, mivel az NDVI nem mutat különbséget a növények fejlödésében az időpontok és területek között, még a 2017. évi egyébként kisebb adatok esetében sem. Kukoricát termesztő kontrollként felhasználhatók voltak Újkígyós 1t-4t kvadrátok 2016. évi adatai, valamint a 6t-7t és 9t-10t 2017-2018. évi EVI adatai is. A 14t nagyon magas EVI értékeihez képest itt is alacsonyabb, 0,58-0,73 közötti értékeket tapasztaltunk. A kukorica esetében, a 
14t több különböző mintaterülethez mért különbségében szerepet játszhat a szennyvíziszap kihelyezés.

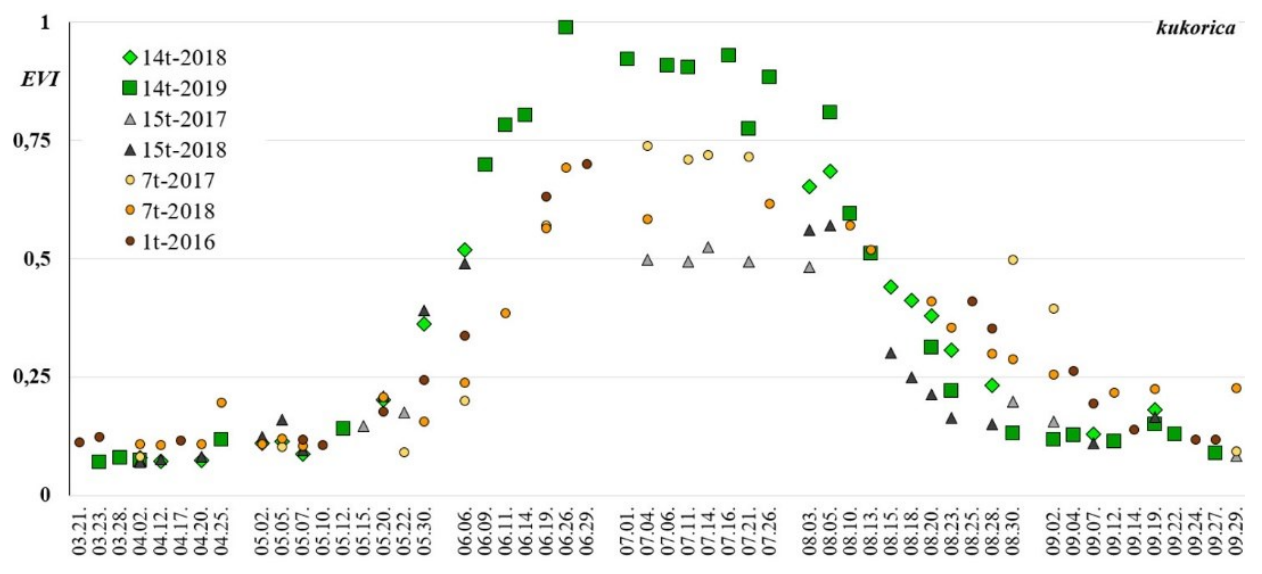

8. ábra

Szennyvíziszap kihelyezés hatása a kukorica EVI értékeire a 14t kvadrát példáján 15t, 7t, $1 \mathrm{t}$ kontrollterületek összehasonlításával.

A kihelyezés hatását az őszi búza termesztésére elöször Újkígyós $1 \mathrm{t}-2 \mathrm{t}$ és $3 \mathrm{t}-4 \mathrm{t}$ 2018. évi, valamint 6t-7t 2019. évi adatain értékeltük úgy, hogy kontrollként a 9t-10t kvadrátok 2019. évi VI értékeihez viszonyítottuk. A kevés időbeli átfedés miatt csak az aratás utáni és következö évi vetés előtti időszak növényzetében (valószínüleg gyomosodás) tapasztaltunk nagyobb növekedést a szennyvíziszappal kezelt területen. Hasonló területhasználati összevetésre került sor Kardos 10t-11t 2019. évi termelésében, ahol kontrollként a 12t-13t-n a 2019. év mellett 2017. nyári félévi adatait használtuk. Utóbbi évben bevontuk a vizsgálatba a $14 t$ kvadrátot is. Az iszap kihelyezésnek nincs hatása az őszi búza vegetáció fejlődésére. A megnevezett kardosi kvadrátok 2019. évi értékei azonosak, sőt a 2017. évi adatok (az aszályos jelleg ellenére) nagyobb produkciós értéket mutatnak. A június végére lezáruló aratást követően sincs semmi különbség, ami az iszap termésnövelő hatására utalna.

A parcellákon belüli VI heterogenitást a kvadrátok térben is jól mintázzák, ahogy az például 2017-2018 május-júniusban is látható (9. ábra). A vegetációs index térbeli különbsége - a diagramokhoz hasonlóan - a kvadrátokon belül általában homogenitást mutat, de ilyen kis mintaterületen is előfordul nagy szórású mintavételezés; pl. 2018.06.06-án. A szennyvíziszap kihelyezések a VI-k térbeliségén a vizsgált időszakban nem változtattak.

Elsősorban a 2017. és 2018. évi száraz nyarakon végzett távérzékelési vizsgálat fedte fel a domborzatot meghatározó alluviális formakincset, a területet ÉK felől D-i irányban „kettészelő” egykori medret, melynek kanyarulata a talajtani adottságok és a biomassza-produktum révén közvetetten rajzolódik ki, egy-egy parcellán belül is terméskülönbséget okozva. A 2t, $3 \mathrm{t}$ és $10 \mathrm{t}$ kvadrátok VI értékeit befolyásolja a talaj 
eltérő fizikai jellege és ebből következő vízgazdálkodási eltérés. A terület keleti felén is látható időszakonként egy, a 4t határában megjelenő medermaradvány vonala.

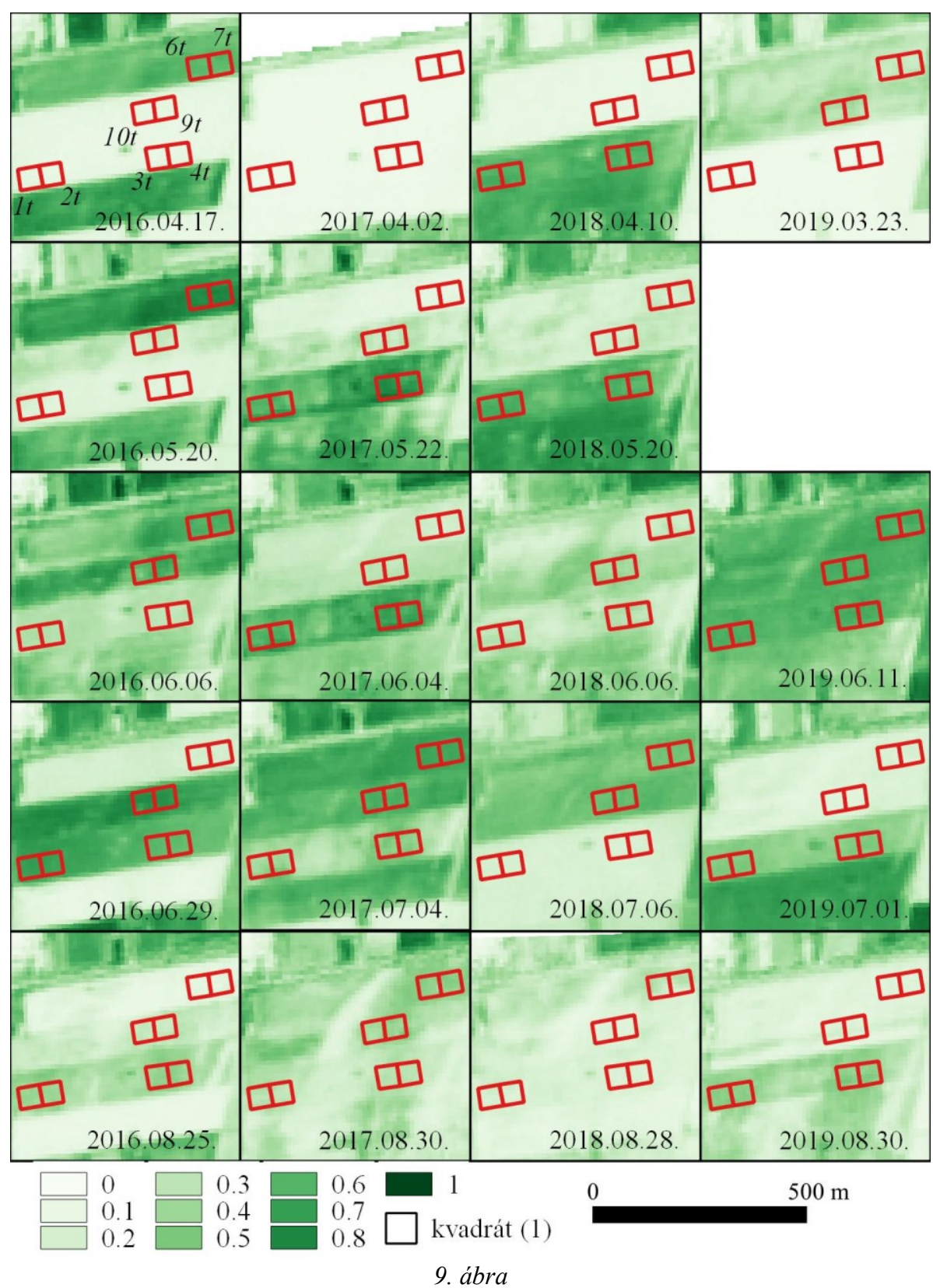

Mezőgazdasági biomassza produkció a Sentinel-2 EVI értékek térbeli eloszlása alapján, Újkígyós mintaterületen a 2016-2019 közötti időszak nyári féléveinek azonos időszakaiban (2019 május adathiányos időszak) 


\section{Összefoglalás}

Az iszapkihelyezések rövidtávú hatásainak megfigyelésére és igazolására több évre kiterjedő, nagy időfelbontású monitoringot terveztünk dél-alföldi, csernozjom talajokon folyamatosan művelt, gyakran évröl-évre különböző növényzettel fedett szántóföldi parcellákon. A $14 \mathrm{db} 50 \mathrm{~m}$ x 50 m-es kvadráton, a Sentinel-2 müholdfelvételezés alapú adatgyüjtést a legnagyobb idő- és térbeli felbontásban alkalmaztuk. Atmoszférikus korrekcióval előfeldolgozott, közel $100 \mathrm{db}$ felhömentes képből álló adatbázist LANDSAT OLI (Operational Land Imager) felvételekkel kiegészítve, vegetációs indexekkel (EVI, NDVI) értékeltük a nyári félév fotoszintetikus aktivitását és biomassza-produkció változásait térben és időben.

A spektrális index alapú vegetációs ciklus különbségek alapján meghatározhatók a területen termelt változatos növényfajok, a felszínfedettség különbségek és a területhasználati változások. A vizsgálatainkkal párhuzamosan, LADÁNYI et al., (2020) szerint értékelt talajtani eredményekhez hasonlóan az iszapkihelyezés által érintett, illetve nem érintett területek között kimutatható, EVI és NDVI-vel mért statisztikai és térbeli különbségek rövidtávon általánosan nem szignifikánsak. A vizsgált négy termény közül a napraforgó, kukorica biomassza produktuma esetén láthatók index különbségek, amelyek az iszapkihelyezés 1-3 éven belül tapasztalható hatásaként értékelhetők, de ennek igazolására folyamatos monitoring vizsgálat szükséges. A repce és az öszi búza esetén a rendelkezésre álló adatok alapján nem tapasztaltunk hasonlót, sőt esetenként a kihelyezés előtti VI értékek magasabbak. A parcellákat jellemző térbeli heterogenitáson - melyet a kvadrátok jól mintáznak - a szennyvíziszap kihelyezések a vizsgált időszakban nem változtattak.

A két különböző vegetációs index együttes alkalmazása hasznos. Az EVI általános előnyei mellett kiemelhető a dús vegetációs időszak értékelésének pontossága, az összehasonlító elemzésben tapasztalható alkalmazhatósága, míg az NDVI a csekélyebb vegetáció dinamikájában, a vegetációtípusok megkülönböztetésében, vagy a dús vegetációt jellemző változékonyság megfigyelésében lehet érzékenyebb. Érdekes, hogy az NDVI és EVI közötti különbség a szennyvíziszappal kezelt területeken kisebb. A várakozásnak megfelelően, a nagy felbontást igénylő vizsgálatban a LANDSAT adatok, a Sentinel alapú indexértékekkel általánosan szoros statisztikai kapcsolatban vannak és igazolják az értékelés eredményeit, de a parcellákon, adott időkben tapasztalt jelentős eltérések miatt önmagukban nem tudják kiegészíteni a vizsgálatot.

A gazdálkodásváltás ellenére kitüzött cél, a szignifikáns különbségek kimutatása indokolja az aktuális évek adatainak további vizsgálatba való bevonását, amely segít az adathiányos időszakok leszükítésében is; 2020. év megfigyelése folyamatban van.

Kulcsszavak: szennyvíziszap, növénytermelés, monitoring, Sentinel-2, spektrális index 
Köszönetnyilvánítás: A kutatást a 'RING2017' - EFOP-3.6.2-16-2017-00010 projekt támogatta.

\section{Irodalom}

36/2006. (V. 18.) FVM rendelet a termésnövelö anyagok engedélyezéséröl, tárolásáról, forgalmazásáról és felhasználásáról

50/2001. (IV. 3.) Kormányrendelet a szennyvizek és szennyvíziszapok mezőgazdasági felhasználásának és kezelésének szabályairól 91/271/EGK irányelv (1991.05.21.) A települési szennyvíz kezeléséröl

86/278/EGK irányelv (1986.06.12.) A szennyvíziszap mezőgazdasági felhasználása során a környezet és különösen a talaj védelméröl

AGROTOPO 1994. MTA TAKI Agrotopográfiai Adatbázis https://maps.rissac.hu:3344/webappbuilder/apps/2/ (utolsó letöltés: 2021.03.29.)

Álvarez, M. M. S., Brown, L. N., LiM, J. B., ERSAhin, K.; Borstad, G. A., Dickson, J., MARTELL, P. 2014. Assessment of vegetation change after biosolids treatment: use of remotely sensed vegetation time series. British Columbia Mine Reclamation Symposium. 1-11.

BANERJEE, M. R., BURTON, D. L., DEPOE, S. 1997. Impact of sewage sludge application on soil biological characteristics. Agriculture. Ecosystems and Environment. 66. (3) 241-249.

BannARi, A., Morin, D., Bonn, F., Huete, A.R. 1995. A review of vegetation indices. Remote Sensing Reviews. 13. 95-120.

DOSOREMI 2017. Országos digitális talajtulajdonság és általánosabb értelemben vett talajtérképek : strukturált webes térképi szolgáltatás. http://dosoremi.hu/table.html (utolsó letöltés: 2021.03.29.)

ESA SENTINEL-2 MISSION: https://sentinel.esa.int/web/sentinel/missions/sentinel-2 (utolsó letöltés: 2020.07.20.)

FARSANG, A., BABCSÁNYI, I., LADÁNyi, Z., Perei, K., BOdOR, A., CSÁNYi, K., BARTA, K. 2020. Evaluating the effects of sewage sludge compost applications on the microbial activity, the nutrient and heavy metal content of a Chernozem soil in a field survey. Arabian Journal of Geosciences. 13. 982

Fiala, K., BARTA, K., BeNYHE, B., FeHÉRVÁRY, I., LÁBDY, J., SiPOS, G., GYŐRFFY, L. 2018. Operatív aszály- és vízhiánykezelő monitoring rendszer. Hidrológiai közlöny. 98. (3) 14-24.

Huete, A., Didan, K., Miura, T., Rodriguez, E.P., GaO, X., Ferreria, L.G. 2002. Overview of the radiometric and biophysical performance of the MODIS vegetation indices. Remote Sensing of Environment. 83. 195-213.

Kelessidis, A., Stasinakis, A.S. 2012. Comparative study of the methods used for treatment and final disposal of sewage sludge in European countries. Waste Management. 32. (6) 1186-1195.

Kovács, F., LadÁnyi, Z., Blanka, V., Szilassi, P., van Leeuwen, B., TobaK, Z., GuláCSI, A., SzAlma, E., CSEUZ, L. 2019. Különböző méretarányú vegetáció monitoring célú távérzékelési adatgyüjtés és -elemzés 2000-től napjainkig a Délkelet-Alföldön és a Vajdaságban. In.: LADÁNYI, Zs.; BLANKA, V. (szerk.) Aszály és belvíz monitoring és menedzsment, valamint a kapcsolódó kockázatok a DélAlföldön és a Vajdaságban. SZTE TFTG Szeged. pp. 34-48. 
LadÁnyi, Z., Csányi, K., Farsang, A., Perei, K., Bodor, A., Kézér, A., Barta, K., BABCSÁNYI, I. 2020. Impact of low-dose municipal sewage sludge compost treatments on the nutrient and the heavy metal contents in a chernozem topsoil near Újkígyós. Hungary: a 5-year comparison. Journal of Environmental Geography. 13. (1-2) 25-30.

LADÁNYI, Z., FARSANG, A., GulÁCSI, A., KovÁcs, F. 2018. The impact of extreme weather conditions and municipal sewage disposal on vegetation using Sentinel images, SE Hungary. In.: ALAPI, T., ILISZ, I. (eds.) Proceedings of the $24^{\text {th }}$ International Symposium on Analytical and Environmental Problems. University of Szeged. pp. 325-329.

LAKATOS, M.; BIHARI, Z.; SZENTIMREY, T. 2014. A klímaváltozás magyarországi jelei. Légkör. 59. (4) 158-163.

Louis, J., Pflug, B.; Main-Knorn, M., Debaecker, V., Mueller-Wilm, U., IANnOne, R. Q., CADAU, E. G., Boccia, V., GASCON, F. 2019. Sentinel-2 global surface reflectance Level-2A product generated with Sen2Cor. In.: IGARSS Symposium. Japan. 8522-8525.

Mezősi, G., BlankA, V., LAdÁNYi, Z., BAtA, T., UrdeA, P., Frank, A., MeYer, B. 2016. Expected mid- and long-term changes in drought hazard for the South-Eastern Carpathian Basin. Carpathian Journal of Earth and Environmental Sciences. 11. (2) $355-366$.

NASA LANDSAT SCIENCE: https://landsat.gsfc.nasa.gov/landsat-8/ (utolsó letöltés: 2020.07.20.)

OGIMET: http://www.ogimet.com/gsynres.phtml.en (utolsó letöltés: 2020.07.20.)

OPERATÍV VÍZHIÁNY ÉRTÉKELŐ ÉS ELÖREJELZŐ RENDSZER: http://aszalymonitoring.vizugy.hu/ (utolsó letöltés: 2020.07.20.)

PetróczKI, F. 2005. A víztelenített szennyvíziszap és a szennyvíziszapból készült komposzt hatása a tavaszi árpa fejlődésére. Acta Agronomica Óváriensis. 46. 25-39.

Puri, V., NAYYAR, A., RAJA, L. 2018. Agriculture drones: A modern breakthrough in precision agriculture. Journal of Statistics and Management Systems. 20. (4) 507-518.

RAKONCZAI, J.; FEHÉR, Z. 2015: A klímaváltozás szerepe az Alföld talajvíz-készleteinek időbeli változásaiban. Hidrológiai Közlöny. 95. (1) 1-15.

SAGASTA, J. M., SALLY, L. R., THEBO, A. 2015. Global wastewater and sludge production, treatment and use. In: Drechsel, P.; Quadir, M.; Wichelns, D. (eds.) Wastewater, Economic Asset in an Urbanizing World. Springer Science+Business Media. pp. $15-38$.

SimON, L.; SzENTE, K. 2000. Szennyvíziszap komposzt hatása a kukorica nitrogéntartalmára, néhány élettani jellemzőjére és hozamára. Agrokémia és Talajtan. 49. 231-246.

SRidhar, B. B. M., Vincent, R. K., Roberts, S. J., CzajKowski, K. 2011. Remote sensing of soybean stress as an indicator of chemical concentration of biosolid amended surface soils. International Journal of Applied Earth Observation and Geoinformation. 13. 676-681.

SRidHAR, B. B. M., Vincent, R. K., Witter, J. D., SpongberG, A. L. 2009. Mapping the total phosphorus concentration of biosolid amended surface soils using LANDSAT TM data. Science of the Total Environment. 407. 2894-2899. 
SzABÓ, A., TAMÁs, J., NAGY, A., ADENIYI, O. D. 2019. Wheat yield prediction based on MODIS NDVI time series data in the wider region of a cereal processing plant. Natural Resources and Sustainable Development. 9. (2) 193-202.

Szabó, S., LÁszló, E., KovÁcs, Z., PÜsPöKI, Z., Kertész, Á., Singh S. K., BALÁzS, B. 2019. NDVI dynamics as reflected in climatic variables: spatial and temporal trends - a case study of Hungary. GIScience and Remote Sensing. 56. (4) 624-644.

SZENNYVÍZISZAP KEZELÉSI ÉS HASZNOSÍTÁSI STRATÉGIA 2014-2023. Országos Vízügyi Főigazgatóság, p.144. http://biopsol.hu/files/file/Szennyviziszap_kezelesi _es hasznositasi_strategia 2018 2023.pdf (utolsó letöltés: 2020.07.20)

TAMÁs, J., BLASKÓ, L. 2008: Environmental management. Digitális Tankönyvtár, Debreceni Egyetem, https://regi.tankonyvtar.hu/hu/tartalom/tamop425/0032 kornyezettechnologia/ch09s06.html (utolsó letöltés: 2020.07.20.)

TOMÓCSIK, A., MAKÁDI, M., OROSZ, V., FÜlEKY, G. 2016. Effect of sewage sludge compost treatment on crop yield. Agrofor International. 1. (2) 5-12.

VERMES, L. 2005. Hulladékgazdálkodás, hulladékhasznosítás. Mezőgazda Kiadó. Budapest.

Vermote, E., Justice, C., Claverie, M., Franch, B. 2016. Preliminary analysis of the performance of the Landsat 8/OLI land surface reflectance product. Remote Sensing of Environment. 185. 46-56.

Zhang, Z., LiU, M., LiU, X., Zhou, G. 2018. A new vegetation index based on multitemporal Sentinel-2 images for discriminating heavy metal stress levels in rice. Sensors. 18. 2172.

\title{
Evaluate the short-term effects of sewage sludge disposal based on Sentinel-2 vegetation monitoring
}

\author{
*Ferenc KovÁCS, Zsuzsanna LADÁNYI \\ Department of Geoinformatics, Physical and Environmental Geography, University of \\ Szeged, Szeged
}

\begin{abstract}
Summary
The agricultural use of sewage sludge is one of the means of refilling the soil nutrients and an effective tool for sustainable environmental management. In order to monitor and verify the short-term effects of sludge disposal (in parallel with other soil observations) we planned a multi-year, high-resolution data collection for monitoring the effects of disposal in some arable land parcels on 14 pieces of $50 \mathrm{~m} \mathrm{x}$ $50 \mathrm{~m}$ quadrates in southeastern Hungary. Using free Sentinel-2, pre-processed satellite imagery, data acquisition was applied at the highest temporal and spatial resolution supplemented with LANDSAT-8 recordings, evaluating the vegetation period from 2016 to 2019 (almost 100 images). We evaluated the photosynthetic activity of the summer season and the changes in biomass production in space and time based on vegetation index (EVI, NDVI).

The difference in the vegetation cycle of the plants on the arable land and the difference in the land use and land cover (LU/LC) are clearly visible in the values of
\end{abstract}


EVI and NDVI. The statistical and spatial index differences between the affected and non-affected areas of sludge disposal are generally not significant in the short term. It can be seen differences in the case of the sunflower and maize biomass products. These can be assessed as the effect of sludge disposal within 1-3 years, but continuous monitoring is required to verify this. In the case of colza and winter wheat (based on the available data) we did not find similar effects, and in some cases the pre-placement EVI/NDVI values were higher.

Vegetation indices heterogeneity among the parcels is also well patterned spatially in the quadrates. The spatial heterogeneity characteristic of the quadrates was not changed by the sewage sludge disposal over the study period. Geometric resolution and monitoring can be used to map a former alluvial form, which is an important factor in understanding parcel yield changes.

We can emphasize the accuracy of EVI evaluation in the dense vegetation period and its applicability in a comparative analysis. NDVI may be more sensitive in the dynamics of smaller or sparse vegetation, or sometimes in the observation of variability characteristic of rich vegetation. It is interesting, that the difference between NDVI and EVI is smaller in areas treated with sewage sludge. LANDSAT data are generally closely related to the Sentinel-based indices values and confirm the results of their evaluation, but they cannot supplement the study on their own due to the significant differences on the parcels at certain times.

In addition to the change of agricultural management, in the detection of significant differences, it is appropriate to measure the data for the following years, that can help to narrow down the data deficient periods; monitoring for 2020 is in progress.

Keywords: sewage sludge, plant cultivation, monitoring, Sentinel-2, spectral index

\section{Figures and Tables}

Figure 1. Study areas and quadrates located between the villages of Kardos and Kondoros, Újkígyós and Szabadkígyós (10t-15t, and 1t-4t, 6t-7t, 9t-10t) (1) study area; (2) national border of Hungary; (3) county border; (4) town; (5) river, lake; (6) quadrat

Figure 2. Monthly precipitation totals and mean air temperature at the Békéscsaba station between 2016-2019 (data: ogimet.com, aszalymonitoring.vizugy.hu) (1) precipitation; (2) temperature

Figure 3. Median and total NDVI values of quadrates of Újkígyós study site between 2016 and 2019 (points: NDVI median, columns: NDVI total) (1t, 2t, 3t and 4t: sewage sludge placing in 2017; 6t and 7t: sewage sludge placing in 2018; $9 \mathrm{t}$ and 10t: no sewage sludge) 
Figure 4. Median and total EVI values of quadrates of Újkígyós study site between 2016 and 2019 (points: EVI median, columns: EVI total) (1t, 2t, 3t and 4t: sewage sludge placing in 2017; 6t and 7t: sewage sludge placing in 2018; $9 \mathrm{t}$ and 10t: no sewage sludge)

Figure 5. Median and total NDVI values of quadrates of Kígyós study site between 2016 and 2019 (points: NDVI median, columns: NDVI total) (10t, 11t and 14t: sewage sludge placing in 2017; 12t, 13t and 15t: no sewage sludge)

Figure 6. Median and total EVI values of quadrates of Kígyós study site between 2016 and 2019 (points: EVI median, columns: EVI total) (10t, 11t and 14t: sewage sludge placing in 2017; 12t, 13t and 15t: no sewage sludge)

Figure 7. Short-term impact of sewage sludge disposal in 2017 on sunflower yield based on Sentinel-2 EVI data from Kardos study site parcels (1) quadrat

Figure 8. Observation of the effect of sewage sludge deposition based on maize EVI values on the example of $14 \mathrm{t}$ quadrat by comparing $15 \mathrm{t}, 7 \mathrm{t}, 1 \mathrm{t}$ control areas

Figure 9. Spatial distribution of agricultural biomass production in the same summer periods of different years based on Sentinel-2 EVI in Újkígyós sample area between 2016-2019 (May 2019: lack of data) (1) quadrat

Table 1. Crops produced on the quadrates of Kardos and Újkígyós study sites between 2016 and 2019. (1) maize; (2) colza; (3) sunflower; (4) oil radish; (5) winter wheat

Table 2. Resolutions of applied Sentinel-2 and Landsat-8 imagery (data: ESA, NASA) (1) multispectral imagery [images/year]; (2) applied spectral bands [nm]; (3) spatial resolution [m]

Open Access nyilatkozat: A cikk a Creative Commons Attribution 4.0 International License (https://creativecommons.org/licenses/by/4.0) feltételei szerint publikált Open Access közlemény, melynek szellemében a cikk bármilyen médiumban szabadon felhasználható, megosztható és újraközölhető, feltéve, hogy az eredeti szerző és a közlés helye, illetve a CC License linkje és az esetlegesen végrehajtott módosítások feltüntetésre kerülnek. (SID_1) 